\title{
Preparations and Applications of Polyethyleneimine-Immobilized Cellulose Fibers for Endotoxin Removal
}

\author{
Sunao Morimoto, Masayo Sakata, Toru Iwata, * \\ Akihiko EsaKI, and Chuichi HiraYAMA ${ }^{\dagger}$ \\ Department of Applied Chemistry, Faculty of Engineering, \\ Kumamoto University, Kumamoto 860, Japan \\ *Kohjin Co., Ltd., Shinbashi 1-1-1, Minato-ku, Tokyo 105, Japan
}

(Received February 6, 1995)

\begin{abstract}
Through the immobilization of polyethyleneimine (PEI) onto cellulose fibers, novel fibrous adsorbents (Cell-PEI fibers) for the removal of endotoxins were prepared. Anionexchange capacity and pore size (molecular mass exclusion, $M_{\text {lim }}$ ) of the Cell-PEI fibers were readily adjusted by changing the ratio of polyethyleneimine and sodium carbonate to cellulose during suspension. The adsorption of endotoxin by the fibers increased with anion-exchange capacity of the fibers, and decreased with increase in the ionic strength of the buffer. The Cell-PEI fibers (anion-exchange capacity 1.1 to $3.0 \mathrm{meq}^{-1}$ ) showed high endotoxin-adsorbing activity at $\mathrm{pH} 5$ to 9 and ionic strength of $\mu=0.05$ to 0.2 . The adsorbing activity for acidic protein such as bovine serum albumin (BSA) increased with $M_{\text {lim }}$ and the anion-exchange capacity of the fibers, but decreased with increase in the ionic strength of the buffer. The Cell-PEI fibers $\left(M_{1 \mathrm{im}}: 2000\right.$, anion-exchange capacity: $1.1 \mathrm{meq}^{-1}$ ) selectively reduced endotoxins in various protein solutions containing endotoxins at $\mathrm{pH} 7$ and $\mu=0.05$. The residual concentration of endotoxins in the protein solutions decreased to less than $0.1 \mathrm{ng} \mathrm{ml}^{-1}$, and recovery rate of the protein was over $98 \%$ in all cases.

KEY WORDS Endotoxin / Pyrogen / Lipopolysaccharide / Selective Removal / Cellulose Fiber / Polyethyleneimine / Bovine Serum Albumin /
\end{abstract}

Endotoxins, constituents of the cell wall of gram-negative bacteria, are pyrogenic lipopolysaccharides (LPS). Their potent biological activity causes pyrogenic and shock reactions in mammals on intravenous injection even in nanogram amounts. ${ }^{1,2} \mathrm{~A}$ number of attempts have been made to remove endotoxins from cell products used as drugs. ${ }^{3,4}$ To remove them from protein solutions, adsorption has proven to be the most effective. Histidine-immobilized cellulose $e^{5,6}$ and polymyxine-immobilized Sepharose $^{7}$ are presently sold as endotoxin adsorbents. However, these adsorbents cannot remove endotoxins selectively, since their adsorbing capacity is high for both endotoxins and acidic proteins such as bovine serum

\footnotetext{
† To whom correspondence should be addressed.
}

albumin (BSA) at low ionic strength of $\mu=0.05$ and neutral $\mathrm{pH}$. When the ionic strength of the buffer increased beyond $\mu=0.2$, the adsorption of BSA decreased, but the adsorption of endotoxins was slight. ${ }^{6}$

Therefore, we attempted to develop endotoxin adsorbents capable of retaining high endotoxin-removing activity at a wide ionic strength range. We previously reported that aminated poly $(\gamma$-methyl L-glutamate) (PMLG) spheres, ${ }^{8,9}$ which have diaminoethane as a ligand, selectively remove endotoxins from various protein solutions at the high ionic strength of $\mu=0.2$ to 0.8 . However, the adsorption of an acidic protein can also be done at a low ionic strength of $\mu=0.05 .^{9}$ 
In this study, we developed novel endotoxin adsorbents that would selectively adsorb endotoxins even at the low ionic strength of $\mu=0.05$. This paper describes the preparations of various polyethyleneimine-immobilized cellulose fibers and effects of pore size and anion-exchange capacity on the selective removal of endotoxins from various cell products.

\section{EXPERIMENTAL}

\section{Materials}

Polyethyleneimine-P1000 (PEI) (molecular weight: $7 \times 10^{4}$, degree of polymerization: 1000 , ratio of primary amine, secondary amine, and tertiary amine: 6/9/5) was kindly supplied by Nippon Shokubai Co., Ltd., Tokyo. Viscose ${ }^{10}$ containing $9.5 \%$ of cellulose was obtained from Kohjin Co., Ltd., Tokyo. Purified endotoxin (Escherichia coli UKT-B LPS) was purchased from Wako Pure Chemical Ind. Ltd., Osaka. Other endotoxins were purchased from Difco Laboratories, Detroit, U.S.A.. Histidine-immobilized cellulose spheres (Pyro Sep-C) were purchased from Daicel, Tokyo. BSA, $\gamma$ globulin, cytochrome C, and a Limulus ES-II test (Limulus amoebocyte lysate) were purchased from Wako. All other chemicals were of analytical reagent grade. Endotoxin-free water was obtained from the Chemo-SeroTherapeutic Research Institute, Kumamoto.

\section{Preparation of the Cell-PEI Adsorbent}

A $10 \mathrm{~kg}$ portion of viscose (containing $9.5 \%$ of cellulose), 0.3 to $1.7 \mathrm{~kg}$ of $30 \mathrm{wt} \%$ PEI solution and 0.3 to $1.5 \mathrm{~kg}$ of $30 \mathrm{wt} \%$ sodium carbonate solution were mixed, and stirred at room temperature for $1 \mathrm{~h}$. The suspension was extruded into a coagulation bath containing $112 \mathrm{gl}^{-1}$ of sulfuric acid, $350 \mathrm{gl}^{-1}$ sodium sulfate, $15 \mathrm{gl}^{-1}$ zinc sulfate, and water through a nozzle having $1 \times 10^{4}$ holes of $0.07 \mathrm{~mm}$ diameter. The regenerated fibers containing PEI were stretched 1.5 times at $95^{\circ} \mathrm{C}$. They were then washed with $0.1 \mathrm{M}$ sodium hydroxide and water, and dried at $105^{\circ} \mathrm{C}$. Five $\mathrm{g}$ of the dried fiber, $6 \mathrm{~g}$ of glutaraldehyde as a crosslinking agent, and $300 \mathrm{ml}$ of water were mixed and suspended by stirring at $50^{\circ} \mathrm{C}$ for $10 \mathrm{~h}$. The fixed cellulose fibers (Cell-PEI) were washed with $0.1 \mathrm{M}$ sodium hydroxide, $0.1 \mathrm{M}$ sodium chloride, and endotoxin-free water. The fibers were cut at a length of about $10 \mathrm{~mm}$. The cuted Cell-PEI fibers were used as adsorbents.

Preparation of the Aminated PMLG Adsorbent Aminated PMLG spheres with diameters of 44 to $105 \mu \mathrm{m}$ were prepared by the suspension evaporation method and aminolysis with diaminoethane. ${ }^{11,12}$

\section{Determination of Anion-Exchange Capacity of the Adsorbent}

The anion exchange capacity of the adsorbent was determined by $\mathrm{pH}$ titration and elemental analysis as described previously. ${ }^{12}$

\section{Determination of Pore Size of the Adsorbent}

The adsorbent was packed into a stainlesssteel column $(150 \times 5 \mathrm{~mm}$ i.d. $)$. Pore size (molecular mass exclusion, $M_{\text {lim }}$ ) of the matrix in the adsorbent was calculated from calibration curves obtained by size exclusion chromatography (SEC) using pullulan standards. We used a JASCO 880-PU pump and Shodex SE-51 refractomonitor. The calibration curves were obtained by plotting average molecular masses against peak elution volumes. $M_{\text {lim }}$ was determined by extrapolating the linear part of each curve as described previously. ${ }^{13,14}$

\section{Adsorption of Endotoxin or Other Substances}

Endotoxin was dissolved in the following buffers: $0.02 \mathrm{M}$ sodium acetate $(\mathrm{pH} 4,5)$, $0.02 \mathrm{M}$ phosphate $(\mathrm{pH} 6,7,8)$, and $0.02 \mathrm{M}$ Tris $(\mathrm{pH} \mathrm{9,10).} \mathrm{The} \mathrm{ionic} \mathrm{strength} \mathrm{of} \mathrm{the} \mathrm{buffer} \mathrm{was}$ adjusted by sodium chloride content. Endotoxin adsorption was measured by a batchwise method as follows. The adsorbent was washed and equilibrated with various buffers 
of different $\mathrm{pH}$ and ionic strength. A $0.2 \mathrm{~g}$ portion of wet Cell-PEI fibers $(100 \mathrm{mg}$ dry weight) was suspended in $2 \mathrm{ml}$ endotoxin solution. The suspension was shaken for $2 \mathrm{~h}$ at $25^{\circ} \mathrm{C}$ and filtered through a Millipore filter $(0.8 \mu \mathrm{m})$ to remove the adsorbent. The endotoxin concentration of the filtrate was determined. The adsorptions of various substances other than endotoxin were estimated by the same endotoxin-binding assay.

\section{Endotoxin Assay}

Endotoxin was assayed by turbidimetry at $660 \mathrm{~nm}$ (a Limulus test method) with a Toxinometer ET-201 (Wako) ${ }^{15}$ using LPS ( $E$. coli $\mathrm{UKT}: \mathrm{B})$ as the standard.

\section{Protein Assay}

Protein concentration was estimated with a Spectrophotometer UV-160(Shimadzu) at 280 $\mathrm{nm}$ (except for cytochrome c at $410 \mathrm{~nm}$ ).

\section{RESULTS AND DISCUSSION}

\section{Effects of Various Factors on the Endotoxin-} Adsorbing Activity of Adsorbents

We previously found that endotoxin-adsorbing capacity increased with amino-group content of adsorbents, but capacity was independent of the kind of amine. ${ }^{8,9}$ Both the histidine-immobilized cellulose and polymyxinimmobilized Sepharose were prepared by immobilization of amino groups onto the spheres through a spacer. However, adsorbents more than $1.0 \mathrm{meq} \mathrm{g}^{-1}$ in anion-exchange capacity could hardly prepared by this method.

In this study, we prepared fibrous Cell-PEI adsorbents by mixing and spinning of viscose and polyethyleneimine to increase anionexchange capacity. As shown in Table I, Cell-PEI fibers with anion-exchange capacities of 0.3 to $3.0 \mathrm{meq} \mathrm{g}^{-1}$ and pore-sizes of 2000 to 35000 at $M_{\text {lim }}$ were prepared. Anion-exchange capacity and pore size of the Cell-PEI fibers were readily adjusted by changing the ratio of polyethyleneimine (ligand) and sodium carbonate (foaming agent) to cellulose in suspension. The endotoxin-adsorbing activities of various Cell-PEI fibers were examined by the batchwise method at $\mathrm{pH} 7.0$ and ionic strength of $\mu=0.05$ (Table I). Standard LPS from E. coli O111:B4 was used as the endotoxin-containing sample. The anion-exchange capacity increased from 0.3 to $3.0 \mathrm{meq} \mathrm{g}^{-1}$ with the ratio of PEI to cellulose from 10 to $60 \mathrm{wt} \% . M_{\text {lim }}$ increased from 2000 to 35000 with foaming-agent ratio

Table I. Effects of the anion exchange capacity and $M_{\text {lim }}$ of the Cell-PEI adsorbents on endotoxin removal

\begin{tabular}{|c|c|c|c|c|c|}
\hline \multicolumn{5}{|c|}{ Adsorbent } & \multirow{2}{*}{$\begin{array}{c}\text { Residual concentration } \\
\text { of endotoxin after } \\
\text { treatment }^{\mathrm{d}}\end{array}$} \\
\hline \multirow{2}{*}{ No. } & PEI ratio ${ }^{a}$ & $\mathrm{Na}_{2} \mathrm{CO}_{3}$ ratio $^{\mathrm{a}}$ & Anion exchange capacity ${ }^{b}$ & \multirow{2}{*}{$M_{\mathrm{lim}}^{\mathrm{c}}$} & \\
\hline & $w t \%$ & wt $\%$ & meq $^{-1}$ & & $\mathrm{ng} \mathrm{ml}^{-1}$ \\
\hline Cell-PEI-10-0 & 10 & 0 & 0.3 & 2000 & 50 \\
\hline Cell-PEI-20-0 & 20 & 0 & 1.1 & 2000 & $<0.1$ \\
\hline Cell-PEI-40-0 & 40 & 0 & 2.2 & 2000 & $<0.1$ \\
\hline Cell-PEI-60-0 & 60 & 0 & 3.0 & 2000 & $<0.1$ \\
\hline Cell-PEI-10-10 & 10 & 10 & 0.3 & 5000 & 55 \\
\hline Cell-PEI-10-20 & 10 & 20 & 0.3 & 10000 & 52 \\
\hline Cell-PEI-10-50 & 10 & 50 & 0.3 & 35000 & 50 \\
\hline
\end{tabular}

${ }^{\mathrm{a}} \mathrm{wt} \%$ to $900 \mathrm{~g}$ of cellulose $\left(10 \mathrm{~kg}\right.$ as viscose) in the suspension. ${ }^{\mathrm{b}}$ Anion exchange capacity of the adsorbent. ${ }^{\mathrm{c}}$ The molecular weight of the largest molecule (pullulan) within the adsorbent. ${ }^{d}$ Removal of endotoxins by the Cell-PEI adsorbent was determined using a batchwise method with $100 \mathrm{mg}$ of adsorbent and $2 \mathrm{ml}$ of endotoxin solution (LPS from E. coli $\left.\mathrm{O} 111: \mathrm{B} 4,500 \mathrm{ng} \mathrm{ml}^{-1} ; \mathrm{pH} 7.0 ; \mu=0.05\right)$. 

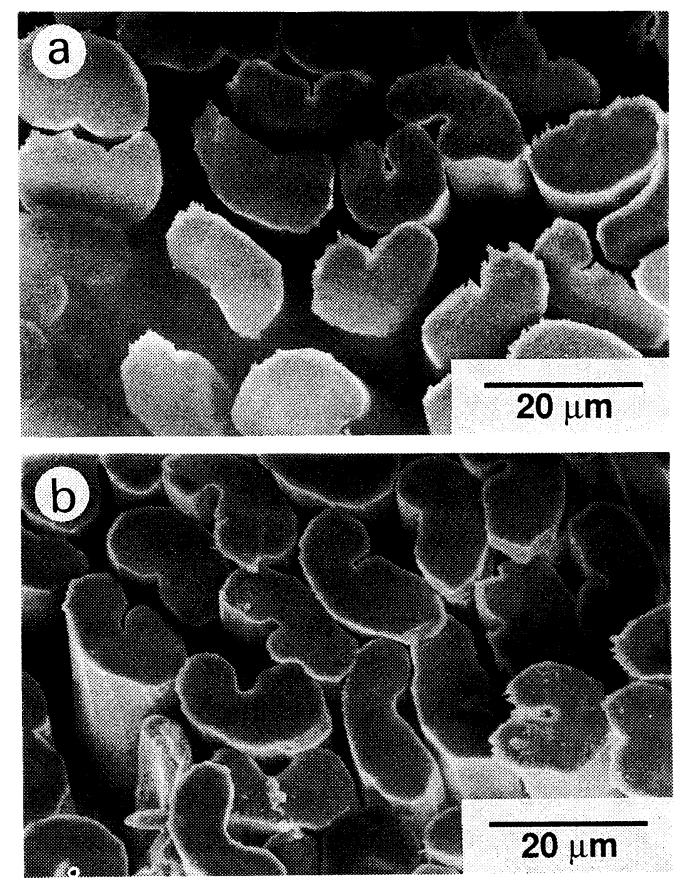

Figure 1. Electron micrographs of Cell-PEI fibers with foaming agent (a) and without (b). $M_{\text {lim }}$ : (a) 35000; (b) 2000. Anion-exchange capacity, $0.3 \mathrm{meq}^{-1}$.

from 0 to $50 \mathrm{wt} \%$. Each adsorbent showed high endotoxin-adsorbing activity. Fibers with anion-exchange capacity of $0.3 \mathrm{meq}^{-1}$ (CellPEI-10-0, 10-10, 10-20, 10-50) showed similar residual concentration ( 50 to $55 \mathrm{ng} \mathrm{ml}^{-1}$ ) of endotoxins. When the anion-exchange capacity increased from 1.1 to $3.0 \mathrm{meq} \mathrm{g}^{-1}$ (Cell-PEI$20-0,40-0,60-0)$, the residual concentration of each endotoxin after treatment decreased to less than $0.1 \mathrm{ng} \mathrm{ml}^{-1}$.

Figure 1 shows electron micrographs of Cell-PEI adsorbents prepared with and without a foaming agent. Each fiber shows a typical viscose-rayon form.

The effects of ionic strength on endotoxin adsorption were examined using Cell-PEI fibers (anion-exchange capacity: 0.3 to $3.0 \mathrm{meq}^{-1}$, $\left.M_{\text {lim }}: 2000\right)$ and histidine-immobilized cellulose spheres (anion-exchange capacity: $0.8 \mathrm{meq} \mathrm{g}^{-1}$, $M_{\text {lim }}: 100000$ ). As shown in Figure 2, the higher the ionic strength of the buffer, the lower the

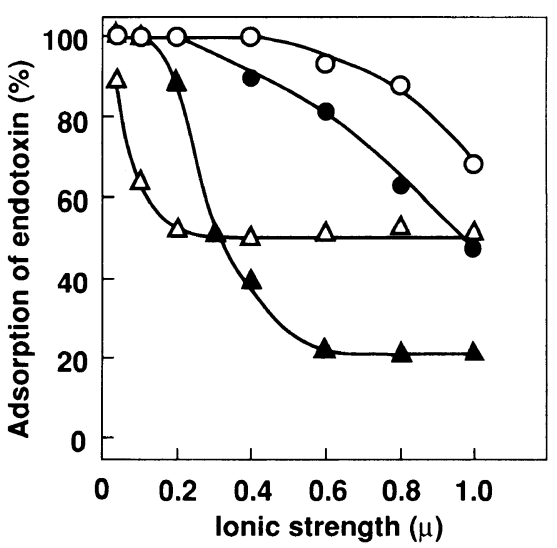

Figure 2. Effects of ionic strength on endotoxinadsorbing activity of various adsorbents. The endotoxinadsorbing activity was determined using the batchwise method with $100 \mathrm{mg}$ adsorbent and $2 \mathrm{ml}$ endotoxin solu-

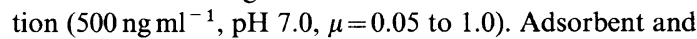
anion-exchange capacity: $O=$ Cell-PEI-60-0, $3.0 \mathrm{meq}^{-1}$; $0=$ Cell-PEI-20-0, 1.1 meq $^{-1} ; \triangle=$ Cell-PEI-10-0, 0.3 meq $\mathrm{g}^{-1} ; \quad \boldsymbol{\Delta}=$ histidine-immobilized cellulose spheres, $0.8 \mathrm{meq}^{-1}$.

endotoxin-adsorbing activity of all adsorbents. At an ionic strength of $\mu=0.05$ to 0.2 and $\mathrm{pH}$ of 7, the Cell-PEI fibers with an anion-exchange capacity of 1.1 (Cell-PEI-20-0) and $3.0 \mathrm{meq}$ $\mathrm{g}^{-1}$ (Cell-PEI-60-0) showed high endotoxinadsorbing activity. The commercially available endotoxin adsorbent, histidine-immobilized cellulose spheres, showed high adsorption for endotoxins at $\mu=0.05$ to 0.1 and $\mathrm{pH} 7$.

The effects of $\mathrm{pH}$ on endotoxins removal by Cell-PEI 20-0 fibers, Cell-PEI-60-0 fibers, and histidine-immobilized cellulose spheres are shown in Figure 3. When the ionic strength of the buffer was adjusted to $\mu=0.05$, Cell-PEI$20-0$ and Cell-PEI-60-0 fibers showed high endotoxin-adsorbing activity at pH 5 to 9 , although the activity decreased at $\mathrm{pH} 4$ and 10. The histidine-immobilized cellulose spheres showed high endotoxin-adsorbing activity at pH 5 to 7.

Since the adsorption of endotoxins was dependent on $\mathrm{pH}$ and ionic strength (Figures 2 and 3), it is suggested that cationic interaction participates in the binding between adsorbent 


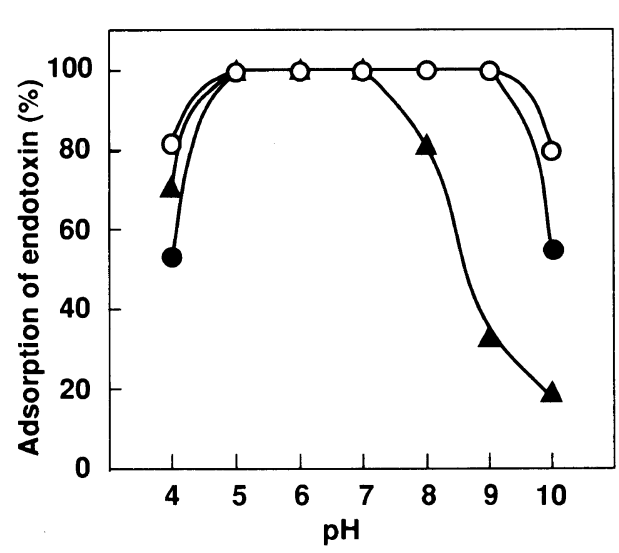

Figure 3. Effects of $\mathrm{pH}$ on endotoxin-adsorbing activity of various adsorbents. Endotoxin-adsorbing activity was determined using the batchwise method with $100 \mathrm{mg}$ adsorbent and $2 \mathrm{ml}$ endotoxin solution $\left(500 \mathrm{ng} \mathrm{ml}^{-1}, \mathrm{pH} 4\right.$ to $10, \mu=0.05$ ). Adsorbent: $\bigcirc=$ Cell-PEI-60-0; $\bigcirc=$ CellPEI-20-0; $\boldsymbol{\Delta}=$ histidine-immobilized cellulose spheres.

and endotoxins. Endotoxins are amphipathic substances which have an anionic region (the phosphoric acid groups) and hydrophobic region (the lipophilic groups). ${ }^{16}$ An endotoxin is anionic at $\mathrm{pH}$ over 4.0 , because $\mathrm{p} K_{\mathrm{a}}$ of the phosphoric acid groups of the endotoxin is below $\mathrm{pH}$ 4.0. The charge of the adsorbents is cationic at $\mathrm{pH}$ below $\mathrm{p} K_{\mathrm{a}} \cdot \mathrm{p} K_{\mathrm{a}}$ (10.5) of polyethyleneimine is higher than that of histidine $\left(\mathrm{p} K_{\mathrm{a}}\right.$ 7.6). The higher the $\mathrm{p} K_{\mathrm{a}}$ of the ligand of the adsorbent, the wider the effective $\mathrm{pH}$ range for endotoxin adsorption. In fact, the effective $\mathrm{pH}$ range for the Cell-PEI fibers is wider than that for the histidine-immobilized cellulose spheres (Figure 3). Cell-PEI-10-0 fibers (anion-exchange capacity: $0.3 \mathrm{meq}^{-1}$ ) can retain about $50 \%$ their endotoxinadsorbing rate at ionic strength of $\mu=0.2$ to 1.0 (Figure 2). The fact that endotoxin adsorption is independent of ionic strength suggests that fibers adsorbed endotoxin due to their hydrophobicity. Minobe et al. ${ }^{6}$ previously found that the adsorption of endotoxins through histidine-immobilized agarose spheres was induced through simultaneous cationic and hydrophobic effect. Thus, the adsorbing activity of the Cell-PEI fibers is induced not only through ionic interactions, but also through some interactions related to hydrophobicity.

\section{Adsorption Behavior Foward Various Proteins}

For the selective adsorption of an endotoxin, it is necessary to reduce the interactions of the adsorbent with proteins. The effects of $M_{\text {lim }}$ and ionic strength of the adsorbents on the adsorption of BSA, an acidic protein, were examined with various adsorbents at ionic strength of $\mu=0.05$ to 0.4 . Cell-PEI fibers with amino-group content of $0.3 \mathrm{meq} \mathrm{g}^{-1}$ and a $M_{\text {lim }}$ of 5000 to 35000 (Cell-PEI-10-10, 10-20, 10-50) and histidine-immobilized cellulose spheres were used. The results are shown Figure 4. The BSA-adsorption rate of Cell-PEI-10-10 fibers $\left(M_{1 \mathrm{im}}: 5000\right)$ was $<1 \%$ in any ionic strength. The BSA-adsorbing capacity of other adsorbents increased with decrease in ionic strength. At low ionic strength $(\mu=0.05)$, the adsorption rate of BSA increased from $<1 \%$ to $58 \%$ with $M_{\text {lim }}$ of the adsorbent from 5000 to 35000 . The histidine-immobilized cellulose spheres with large pore size $\left(M_{\mathrm{lim}}: 100000\right)$ also showed high adsorption rate $(89 \%)$ of BSA at a low ionic strength of $\mu=0.05$. These results (Figures 2, 3, and 4) suggest that Cell-PEI fibers with $M_{\text {lim }}$ below 5000 can adsorb endotoxins without affecting BSA recovery.

The effects of the amino-group content of the adsorbent on the selective removal of endotoxins from a BSA solution (BSA 500 $\mu \mathrm{g} \mathrm{ml}^{-1}$, LPS from E. coli O111:B4 500 $\mathrm{ng} \mathrm{ml} \mathrm{m}^{-1}$ ) were investigated using the CellPEI fibers (anion-exchange capacity, 0.3 to 3.0 meq $\left.\mathrm{g}^{-1} ; M_{\text {lim }}, 2000\right)$ (Figure 5). Cell-PEI fibers with an anion-exchange capacity of 1.1 to 3.0 meq $\mathrm{g}^{-1}$ removed endotoxin from the BSA solution, but the adsorption ratio of BSA increased with anion-exchange capacity. When the anion-exchange capacity was $1.1 \mathrm{meq} \mathrm{g}^{-1}$ and $M_{\text {lim }}$ was 2000 , the fibers (Cell-PEI-20-0) were able to efficiently remove endotoxin from a BSA solution without any loss of BSA.

The effect of buffer's ionic strength on the 


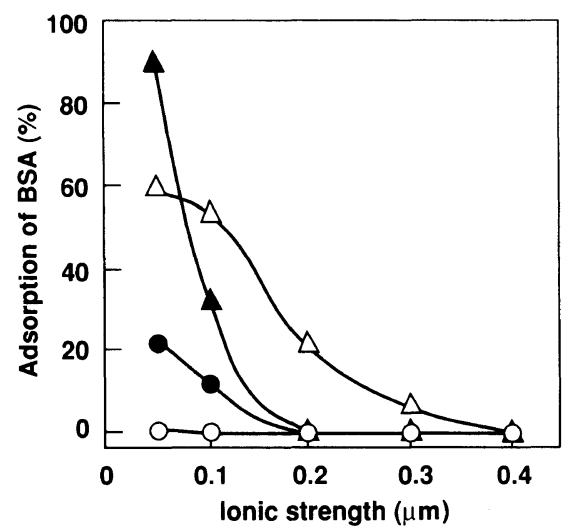

Figure 4. Effects of $M_{\text {lim }}$ and ionic strength on the BSAadsorbing activity of various adsorbents. BSA-adsorbing capacity was determined using the batchwise method with $100 \mathrm{mg}$ adsorbent and $2 \mathrm{ml}$ BSA solution $(500 \mu \mathrm{g}$ $\left.\mathrm{ml}^{-1}, \mathrm{pH} 7, \mu=0.05-0.4\right) . M_{\text {lim }}: \mathrm{O}=$ Cell-PEI-10-10, 5000; =Cell-PEI-10-20, 10000; $\triangle=$ Cell-PEI-10-50, 35000; $\boldsymbol{\Delta}=$ histidine-immobilized cellulose spheres, 100000. Anion-exchange capacity: Cell-PEI fibers, 0.3 meq $\mathrm{g}^{-1}$; histidine-cellulose spheres, $0.8 \mathrm{meq}^{-1}$.

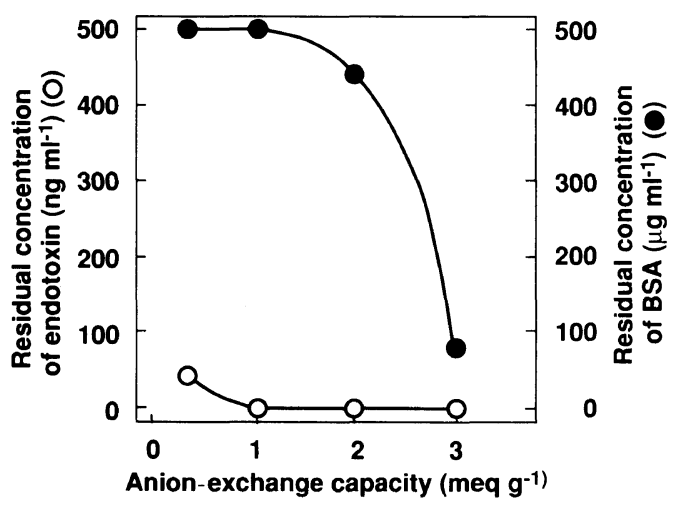

Figure 5. Effects of anion-exchange capacity on the removal of endotoxins from a BSA solution by Cell-PEI fibers $\left(M_{\text {lim }}, 2000\right.$; anion-exchange capacity, 0.3 to 3.0 meq $\left.\mathrm{g}^{-1}\right)$. The removal of endotoxin was determined using the batchwise method with $100 \mathrm{mg}$ adsorbent and $2 \mathrm{ml}$ sample solution (BSA, $500 \mu \mathrm{g} \mathrm{ml}^{-1}$; LPS from E. coli

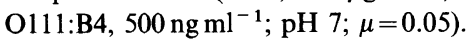

selective removal of endotoxin from a BSA solution by various adsorbents was examined. As shown in Figure 6a, Cell-PEI-20-0 fibers selectively removed endotoxin from a BSA solution at ionic strength of $\mu=0.05$ to 0.2 . The aminated PMLG spheres (Figure 6b)

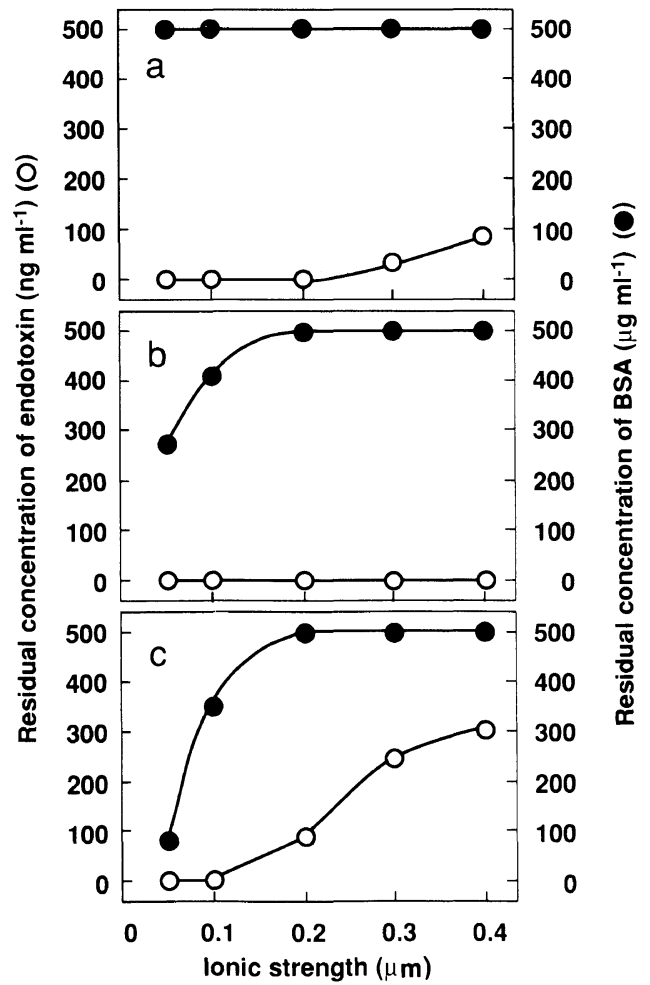

Figure 6. Effects of ionic strength on the removal of endotoxins from a BSA solution by various adsorbents. The removal of endotoxin was determined using the batchwise method with $100 \mathrm{mg}$ adsorbent and $2 \mathrm{ml}$ of sample solution (BSA, $500 \mu \mathrm{g} \mathrm{ml}^{-1}$; LPS from E. coli O111:B4, $500 \mathrm{ng} \mathrm{ml}^{-1} ; \mathrm{pH} 7 ; \mu=0.05$ to 0.4$)$. Adsorbent, $M_{\text {lim }}$, and anion-exchange capacity: (a) Cell-PEI-20-0 fibers, 2000, 1.1 meq g $^{-1}$; (b) aminated PMLG spheres, 8000, $1.4 \mathrm{meq} \mathrm{g}^{-1}$; (c) histidine-immobilized cellulose spheres, $100000,0.8$ meq $^{-1}$.

showed high endotoxin-adsorbing activity for both endotoxins and BSA at low ionic strength of $\mu=0.05$, but they selectively remove endotoxins at high ionic strength of $\mu=0.2$ to 0.4 . We previously reported that aminated PMLG spheres maintain high endotoxinremoving activity even at the high ionic strength of $\mu=1.0 .^{9}$ This is because the hydrophobicity of the PMLG spheres is higher than that of cellulose and agarose spheres. ${ }^{17}$ Histidine-immobilized cellulose spheres had high endotoxin-adsorbing activity at $\mu=0.05$ to 0.1 , but BSA was also adsorbed. When ionic 
strength increased to $\mu=0.2$, the adsorption of BSA by the spheres decreased, but this ionic strength was accompanied by decrease in the adsorption of endotoxin (Figure 6c). The histidine-immobilized cellulose, therefore, cannot remove endotoxin from a BSA solution at any ionic strength. Almost no $\gamma$-globulin (a neutral protein) or cytochrome c (a basic protein) was adsorbed by any adsorbent under any conditions.

Protein charge is anionic at $\mathrm{pH}$ over $\mathrm{pI}$ and is cationic at $\mathrm{pH}$ under it. Accordingly, the most favorable $\mathrm{pH}$ for selectively removing endotoxins present in protein solutions is below $\mathrm{pI}$ of the proteins and above $\mathrm{p} K_{\mathrm{a}}$ of the phosphoric acid residues of the endotoxins. All adsorbents we used readily removed endotoxins from a cytochrome $\mathrm{c}$ or $\gamma$-globulin solution at $\mathrm{pH} 7$ without loss of protein. This is because the ionic interaction of the adsorbent with cytochrome c ( $\mathrm{pI}$ 10.6) and $\gamma$-globulin (pI 7.4) is not induced at $\mathrm{pH} 7.0$ (less than $\mathrm{pI}$ ).

In contrast, acidic high-molecular weight substances (such as BSA) are anionic at $\mathrm{pH} 7.0$ (over pI), and are adsorbed well by cationic adsorbents. To selectively adsorb endotoxins in the BSA solution, it is necessary to decrease $\mathrm{pH}$ of the buffer to less than 4.9 (pI of BSA), but at such a low $\mathrm{pH}$, the endotoxin-adsorbing activity of the adsorbents decreases (Figure 3).

On the other hand, the adsorption of BSA was dependent on the pore size of the matrix. As shown in Figure 4, the adsorbents with $M_{\text {lim }}$ over 5000 (Cell-PEI-10-20 and 10-50 fibers, histidine-immobilized cellulose, and aminated PMLG spheres) adsorbed BSA at $\mu=0.05$ and pH 7. In contrast, almost no BSA was adsorbed by Cell-PEI-20-0 spheres $\left(M_{\text {lim }}: 2000\right)$ at any ionic strength (Figure 4). These results show that the adsorption of BSA is caused by its entry into the pores of the adsorbent.

We previously ${ }^{9}$ reported that endotoxins cannot enter pores with $M_{\text {lim }}<400000$ because they form supermolecular aggregates $\left(M_{\text {lim }}\right.$ $>1000000)$. Endotoxins, however, were adsorbed very well by the Cell-PEI-20-0 fibers
( $\left.M_{\text {lim }}: 2000\right)$. Therefore, we assume that the endotoxins are also adsorbed on the surface of the Cell-PEI-20-0 fibers, but that BSA are not.

It is suggested that the fibers bind more strongly with endotoxins than with BSA, even at low ionic strength. This is because the fibers can adsorb endotoxins not only through their cationic properties but also through their hydrophobic properties, and because endotoxins have lower $\mathrm{p} K_{\mathrm{a}}$ and higher hydrophobicity than BSA.

These results (Figures 4, 5, and 6) show that it is effective for selective adsorption of endotoxin to adjust the anion-exchange capacity of the adsorbent to 1 to $2 \mathrm{meq} \mathrm{g}^{-1}$ and pore size $\left(M_{\text {lim }}\right)$ to less than 5000 . Anionexchange capacity is adjustable in spite of the fact that the shape of adsorbents is spherical or fibrous. However, it is difficult to adjust $M_{\text {lim }}$, because the introduction of ligands such as amino groups often increases the swelling degree of the adsorbents. For example, we observed that the $M_{\text {lim }}$ increases from 500 to 8000 by introducing 3 meq $\mathrm{g}^{-1}$ of amino groups in the case of the amination of PMLG spheres. In contrast, Cell-PEI fibers were prepared without such amination. The high endotoxinselectivity of Cell-PEI-20-0 fibers can be explained by the fact that the fibers have smaller pores $\left(M_{\mathrm{lim}}, 2000\right)$ than the aminated PMLG $\left(M_{\text {lim }}, 8000\right)$ and histidine- immobilized cellulose $\left(M_{\text {lim }}, 100000\right)$.

\section{Adsorption Behavior Foward Various En- dotoxins}

The adsorptions of purified endotoxins from various gram-negative bacteria by Cell-PEI20-0 fibers are summarized in Table II. When adsorption was measured in water, the Cell-PEI-20-0 fibers completely removed the endotoxins. At pH 7.0 and $\mu=0.1$ and 0.2 , the residual concentrations of endotoxins from $E$. coli UKT-B, O111:B4, and B. pertussis decreased from 500 to less than $0.01 \mathrm{ng} \mathrm{ml}^{-1}$, but all other endotoxins were not completely removed. These results show that the en- 
Table II. Adsorption of endotoxins originating from various gram-negative bacteria by Cell-PEI-20-0

\begin{tabular}{|c|c|c|c|}
\hline \multirow[b]{2}{*}{ Endotoxin $^{a}$} & \multicolumn{3}{|c|}{ Residual concentration of endotoxin after treatment/ng ml ${ }^{-1 b}$} \\
\hline & Water & $\begin{array}{c}\text { Buffer } \\
(\mathrm{pH} 7.0, \mu=0.05)\end{array}$ & $\begin{array}{c}\text { Buffer } \\
(\mathrm{pH} 7.0, \mu=0.2)\end{array}$ \\
\hline Escherichia coli UKT-B & $<0.001$ & $<0.001$ & $<0.01$ \\
\hline Escherichia coli O111:B4 & $<0.001$ & $<0.001$ & $<0.01$ \\
\hline Escherichia coli $\mathrm{O} 127: \mathrm{B} 8$ & $<0.001$ & 2.1 & 12.0 \\
\hline Escherichia coli $\mathrm{O} 55: \mathrm{B} 5$ & $<0.001$ & 0.01 & 0.2 \\
\hline Salmonella typhosa 0901 & $<0.001$ & 0.05 & 0.8 \\
\hline Salmonella typhimurium & $<0.001$ & 0.2 & 1.8 \\
\hline Bordetella pertussis Tohama & $<0.001$ & $<0.001$ & $<0.001$ \\
\hline
\end{tabular}

${ }^{\text {a }}$ The purified endotoxin was dissolved in water and a phosphate buffer $(\mathrm{pH} 7.0, \mu=0.05$ or 0.2 ) at a concentration of $500 \mathrm{ng} \mathrm{ml}^{-1}$. ${ }^{\mathrm{b}}$ The adsorption of the endotoxin was determined using a batchwise method with $0.1 \mathrm{~g}$ of adsorbent and $2 \mathrm{ml}$ of endotoxin solution.

Table III. Removal ${ }^{\mathrm{a}}$ of the endotoxin from various protein solutions by Cell-PEI-20-0 adsorbent

\begin{tabular}{|c|c|c|c|c|}
\hline \multirow{2}{*}{$\begin{array}{c}\text { Protein } \\
\left(500 \mu \mathrm{g} \mathrm{ml}^{-1}\right)\end{array}$} & \multicolumn{2}{|c|}{ Concentration of endotoxin $/ \mathrm{ng} \mathrm{ml}^{-1}$} & \multirow{2}{*}{$\begin{array}{c}\text { Endotoxin removed } \\
\%\end{array}$} & \multirow{2}{*}{$\frac{\text { Recovery of protein }}{\%}$} \\
\hline & Before treatment & After treatment & & \\
\hline BSA & $22 \mathrm{~b}$ & 0.07 & 99 & 98 \\
\hline Myoglobin & $0.9^{b}$ & 0.02 & 98 & 99 \\
\hline$\gamma$-Globulin & $8.6^{\mathrm{b}}$ & 0.05 & 99 & 99 \\
\hline Cytochrome c & $1.2^{\mathrm{b}}$ & $<0.01$ & 99 & 100 \\
\hline
\end{tabular}

${ }^{\text {a }}$ The removal of the endotoxin was determined using a batchwise method with $250 \mathrm{mg}$ of the adsorbent and $5 \mathrm{ml}$

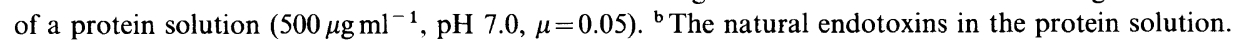

dotoxin-adsorbing activity of Cell-PEI fibers differs with the kind of endotoxin.

\section{Selective Removal of Endotoxin from Protein- Containing Solutions}

Table III shows the selective removal of endotoxins from various protein solutions containing natural endotoxins with Cell-PEI-20-0 fibers. The proteins were naturally contaminated with endotoxins at concentrations varying from 0.9 to $22 \mathrm{ng} \mathrm{ml}^{-1}$. The fibers showed high recovery (98 to $100 \%$ ) of protein as well as high removal (98 to $99 \%$ ) of endotoxins at $\mathrm{pH} 7$ and $\mu=0.05$. It is essential to eliminate the endotoxins, or at least decrease them to a concentration of $0.1 \mathrm{ng} \mathrm{ml}^{-1}$, from fluids used in intravenous injections, ${ }^{6}$ since their potent biological activity elicits pyrogenic and shock reactions in mammals. ${ }^{1,2}$ As shown in Table III, Cell-PEI-20-0 fibers decreased endotoxins in all sample to less than $0.1 \mathrm{ng} \mathrm{ml}^{-1}$ without any loss of protein.

\section{CONCLUSION}

Cell-PEI fibers can remove endotoxins from various proteins, even at low ionic strength of $\mu=0.05$ without affecting protein recovery. This selective removal activity of Cell-PEI fibers is due to (1) simultaneous effects of cationic properties of amino groups and hydrophobic properties of the matrix alkyl chains, and (2) exclusive effects on protein molecules when the $M_{\text {lim }}$ rate is less than 5000 . 
In addition, Cell-PEI-20-0 fibers can be readily produced on a large scale at low cost.

Acknowledgments. We are greatful to Dr. M. Kitano of Nippon Shokubai Co., Ltd. for measuring the amine ratio of the polyethyleneimine-P1000 used in this study.

\section{REFERENCES}

1. S. I. Morse, Adv. Appl. Microbiol., 20, 9 (1976).

2. D. C. Morrison and R. J. Ulevitch, Am. J. Pathol., 93, 527 (1978).

3. K. J. Sweadner, M. Forte, and L. L. Nelsen, Appl. Environ. Microbiol., 34, 382 (1977).

4. S. Ohkido, Nippon Kagaku Kaishi, 1547 (1973).

5. S. Minobe, T. Watanabe, T. Sato, and I. Chibata, $J$. Chromatogr., 248, 401 (1982).

6. S. Minobe, T. Watanabe, T. Sato, and T. Tosa, Biotechnol. Appl. Biochem., 10, 143 (1988).

7. T.E. Karprus, R. J. Ulebitch, and C. B. Wilson, $J$.
Immunol. Methods, 105, 221 (1987).

8. C. Hirayama, M. Sakata, Y. Ohkura, H. Ihara, and K. Ohkuma, Chem. Pharm. Bull., 40, 2106 (1992).

9. C. Hirayama, M. Sakata, H. Ihara, K. Ohkuma, and M. Iwatsuki, Anal. Sci., 8, 805 (1992).

10. H. P. Bucher, "Man-Made Fibers, Science and Technology," John Wiley \& Sons, New York, 1968, p 7.

11. C. Hirayama and H. Ihara, J. Chromatogr., 347, 357 (1985).

12. C. Hirayama, H. Ihara, and X. Li, J. Chromatogr. Biomed. Appl., 530, 148 (1990).

13. K. A. Granth and P. Flodin, Makromol. Chem., 48, 160 (1961).

14. H. Ihara, T. Yoshinaga, and C. Hirayama, J. Chromatogr., 362, 197 (1986).

15. H. Ohishi, Y. Hatoyama, H. Shiraishi, and K. Yanagisawa, Yakugaku Zasshi, 105, 300 (1985).

16. O. Westphal, O. Luderitz, C. Galanos, H. Mayer, and E. T. Rietschel, Adv. Immunopharmacol., 3, 13 (1986).

17. Y. Motozato, H. Ihara, M. Nakamura, M. Shiba, and C. Hirayama, Nippon Kagaku Kaishi, 61 (1988). 